\title{
Musashi-1: An Example of How Polyalanine Tracts Contribute to Self-Association in the Intrinsically Disordered Regions of RNA-Binding Proteins
}

\author{
Tsai-Chen Chen ${ }^{1}$ and Jie-rong Huang ${ }^{1,2, *(D)}$ \\ 1 Institute of Biochemistry and Molecular Biology, National Yang-Ming University, \\ No. 155 Section 2 Li-nong Street, Taipei 11221, Taiwan; hazelnut.chen.scu@gmail.com \\ 2 Institute of Biomedical Informatics, National Yang-Ming University, No. 155 Section 2 Li-nong Street, \\ Taipei 11221, Taiwan \\ * Correspondence: jierongh@ym.edu.tw
}

Received: 3 March 2020; Accepted: 24 March 2020; Published: 26 March 2020

\begin{abstract}
RNA-binding proteins (RBPs) have intrinsically disordered regions (IDRs) whose biophysical properties have yet to be explored to the same extent as those of the folded RNA interacting domains. These IDRs are essential to the formation of biomolecular condensates, such as stress and RNA granules, but dysregulated assembly can be pathological. Because of their structural heterogeneity, IDRs are best studied by NMR spectroscopy. In this study, we used NMR spectroscopy to investigate the structural propensity and self-association of the IDR of the RBP Musashi- 1 . We identified two transient $\alpha$-helical regions (residues 208-218 and 270-284 in the IDR, the latter with a polyalanine tract). Strong NMR line broadening in these regions and circular dichroism and micrography data suggest that the two $\alpha$-helical elements and the hydrophobic residues in between may contribute to the formation of oligomers found in stress granules and implicated in Alzheimer's disease. Bioinformatics analysis suggests that polyalanine stretches in the IDRs of RBPs may have evolved to promote RBP assembly.
\end{abstract}

Keywords: RNA-binding proteins; intrinsically disordered proteins; polyalanine; liquid-liquid phase separation; self-association

\section{Introduction}

The human genome encodes more than 1500 RNA-binding proteins (RBPs) [1]. In addition to canonical RNA-binding domains, most, if not all, RBPs have intrinsically disordered regions (IDRs) [2-5], whose importance has only recently come to light [6,7]. Pioneering studies have shown that some RBPs (including FUS, hnRNPA1, hnRNPA2 and TIA1) use their IDRs to form "dynamic fibers" that may play a role in organizing membraneless cellular structures, such as RNA granules and stress granules [8]. Another function mediated by IDRs is liquid-liquid phase separation (LLPS), which has recently been shown to govern the coordination of cellular membraneless organelles $[9,10]$. RBPs are the protein family whose IDR-mediated LLPS has been the most studied, notably in terms of the effect of mutations on functional assembly and pathological aggregation [11,12], interactions with other molecules that disrupt or promote self-assembly $[13,14]$, posttranslational modification effects $[15,16]$, residues or sequence motifs that promote condensation $[17,18]$, and their regulation in alternative splicing $[19,20]$. In spite of the growing literature on these IDRs, residue-specific information, which would provide crucial functional insights, is available for just a few members [21-24] of this 1500+ family. More structural studies of these IDRs are required to improve our understanding and deduce family-wide rules. 
Musashi- 1 is a particularly interesting RBP. Its roles in mediating stem cell regeneration and cell differentiation are well-known [25], and recent evidence suggests it may be implicated in neurodegenerative diseases [26,27], as have the prominent RBPs TDP-43 and FUS [28,29]. The removal of Musashi-1's IDR prevents this protein's recruitment to stress granules that reduce the chemoresistance of some types of cancer cells $[30,31]$. This role in granule formation resembles those of other neurodegeneration-associated RBPs; for example, FUS forms liquid-like compartments under stress that recruit proteins to repair damaged DNA, but can also transition to a fibrous, pathological state [11]; likewise, hnRNPA1 acts as a scaffold for stress granules, but this can also lead to pathological aggregation [12].

Musashi-1's IDR differs in its primary sequence from many of those that have been studied to date. Although its RNA recognition motifs (as predicted by PROSITE [32] and in experimentally solved structures [33,34]) and low sequence complexity (predicted by the SEG algorithm [35]) are similar to those of other known RBPs, the levels of structural disorder predicted for the C-terminal part (residues 194-362; Figure 1A,B) vary depending on the algorithm used. This is probably because of the predominance of hydrophobic residues and the low proportion of charged residues (Figure 1C,D), which are features of folded proteins-as also shown by FoldIndex predictions [36] and its location in the charge-hydropathy plot (Figure 1E,G). Unlike other RBPs implicated in neurodegenerative diseases (see Supplementary Figure S1 for examples), it is not prion-like (Figure 1F). Another unusual feature of its primary sequence is the presence of a polyalanine tract (eight consecutive alanines) in the center, and contrary to the IDRs of many other RBPs [4,5], there are no SR-repeats, RG/RGG motifs, $\mathrm{Q} / \mathrm{N}$-rich stretches, or [G/S]Y[G/S] motifs (Figure $1 \mathrm{H}$ ). How this unique sequence is involved in neurodegenerative disease and/or stress granule recruitment are questions that remain to be answered. In this study, we used NMR spectroscopy to obtain residue-specific information on the IDR, revealing two parts with $\alpha$-helical propensity. In combination with circular dichroism (CD) and micrography data, the NMR results suggest that the helices are involved in self-association. More generally, the fact that one of the helices in the polyalanine stretch is also found in many other RBPs suggests that polyalanine tracts may have evolved as a means of self-assembly. 


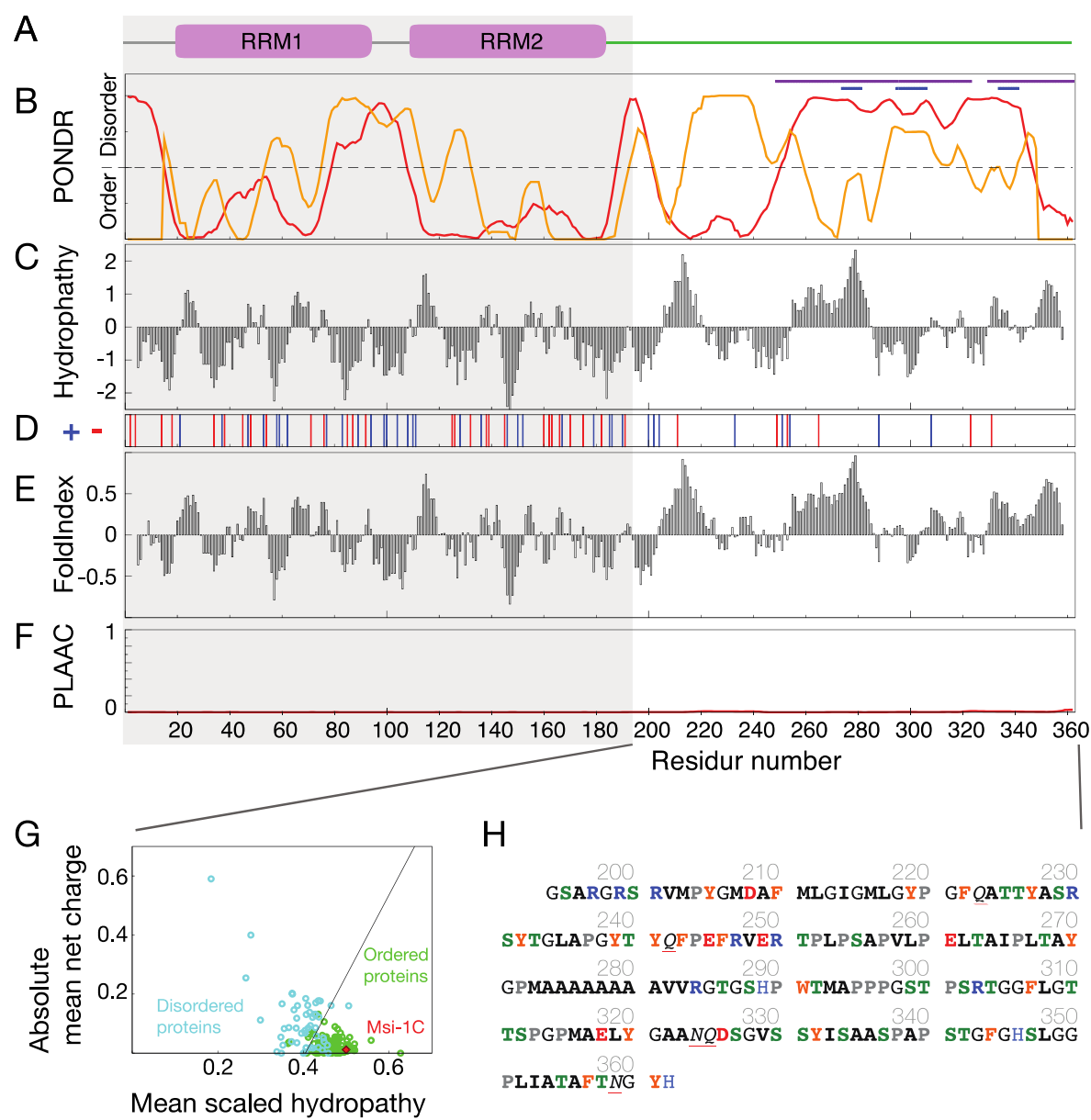

Figure 1. Primary sequence analysis of Musashi-1. (A) Functional domains predicted by PROSITE [32] and deposited structures. (B) Levels of protein disorder predicted by the PONDR VLXT (red) and XL1_XT (yellow) algorithms [37]. The two regions with low sequence complexity predicted using the SEG algorithm [35] are shown with blue and purple bars. (C) Hydropathy according to the Kyte and Doolitte scale (average window size: 9). The scale of each amino acid is derived from experimental observations from solved structures [38]. (D) Positions of positively (blue) and negatively (red) charged residues. (E) FoldIndex folding [36]. (F) Prion-likeness predicted by the PLAAC algorithm [39]. (G) Charge-hydropathy plot for a database of known disordered proteins (blue) and folded proteins (green) and the residues 194-362 of Musashi-1 (red) [37]. (H) The primary sequence used in this study, with residues labeled according to their properties (blue: positive; red: negative; green: potential phosphorylation sites; orange: aromatic residues; gray: prolines; black: hydrophobic residues).

\section{Results and Discussion}

\subsection{Chemical Shift Assignment of Musashi-1}

The chemical shift assignments for the IDRs of Musashi-1 (residues 194-362; BMRB access number: 50204 ) are shown in Figure 2A ( $\mathrm{pH} 5.5,283 \mathrm{~K})$. The protein is prone to aggregation and proline-rich ( $\sim 12 \%$ in the sequence), so a specific assignment strategy was used, as described in the Material and Methods section and the Supplementary Information. Although the PASTA algorithm [40] predicts four $\alpha$-helices based on the primary sequence (Figure 2B), secondary chemical shift analysis indicates that just two regions, residues $\sim 208-218$ and $\sim 270-284$, form transient $\alpha$-helices (Figure 2C-E), with populations (predicted using the $\delta 2 \mathrm{D}$ algorithm [41] derived from the molecular dynamics simulation and experimental observations of conformational equilibrium of multiple states, using $\mathrm{C} \alpha, \mathrm{C} \beta, \mathrm{C}^{\prime}, \mathrm{HN}$, and $\mathrm{NH}$ chemical shifts) of $28 \%$ and $45 \%$ at most (Figure $2 \mathrm{~F}$ ). 
A

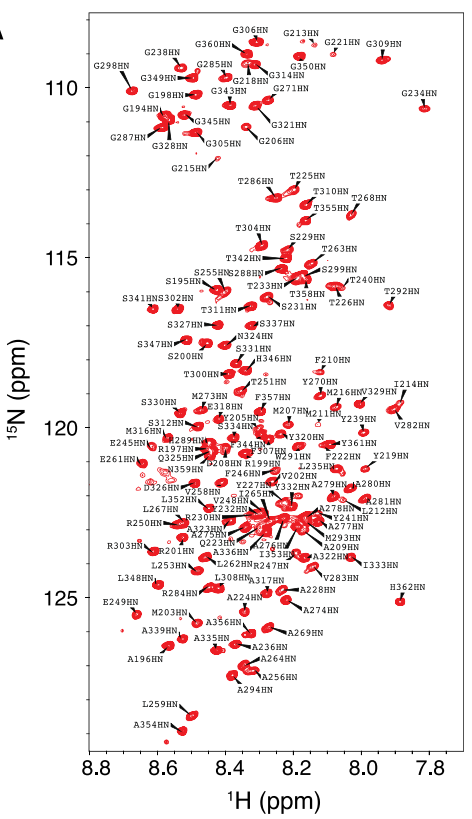

B

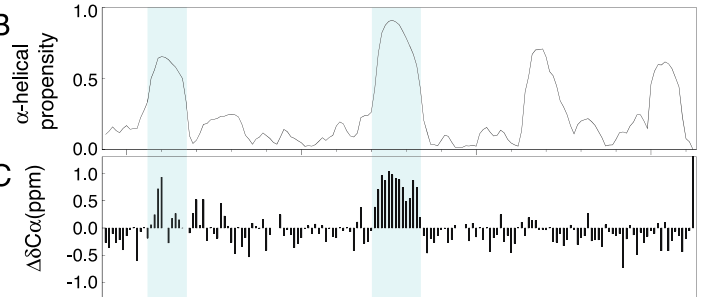

$\mathrm{D} \hat{\mathrm{\varepsilon}} 1.0$

흥 0.5

离 0.0

-1.0 .
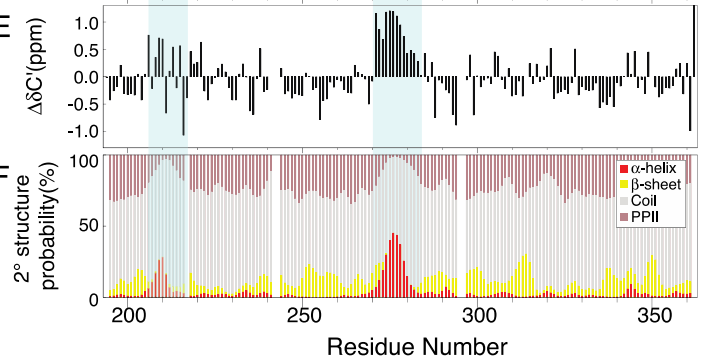

Figure 2. NMR chemical shift assignment of Musashi-1. (A) HSQC spectrum of Musashi-1 at $283 \mathrm{~K}$ and pH 5.5 with peak assignments. Except L217, Q242, F243, and L319, all non-proline peaks are assigned. (B) Residue-specific $\alpha$-helical propensities predicted using the PASTA program. (C-E) Secondary chemical shifts for $C \alpha(C), C \beta(D)$, and $C^{\prime}($ E) atoms. (F) Stacked plot of secondary structure probability based on the assigned chemical shifts, calculated using the $\delta 2 \mathrm{D}$ algorithm (red: $\alpha$-helix; yellow: $\beta$-sheet; gray: random coil; brown: polyproline II helix).

\subsection{Musashi-1 Self-Association}

The implication of Musashi-1 in neurodegenerative diseases and the role of its IDR in stress granule recruitment $[30,31]$ suggest that it has a propensity to self-assemble as observed in many RBPs $[11,12,23]$. The HSQC spectra measured for 20 and $100 \mu \mathrm{M}$ protein samples at $\mathrm{pH} 5.5$, under different temperatures (Figure 3A), show decreased intensities in the N-terminal region, between the two $\alpha$-helical elements. Many of the peaks in the HSQC spectra have distorted line shapes, notably those from residues in between and within the two helical stretches, because of the kinetics among many conformations (monomer and oligomer) in the intermediate exchange regime (Figure 3B; representative peaks that are not distorted or broadened are shown in Supplementary Figure S2). The peak intensity ratios between the two protein concentrations are less than the corresponding molar ratio (Figure 3C). Furthermore, the average intensity ratio is lower at higher temperatures (3.51, 3.17 , and 2.05 at 283,293 , and $303 \mathrm{~K}$, respectively, compared with a molar ratio of 5). At $283 \mathrm{~K}$, the intensity ratios in the first $\alpha$-helical region are even lower, suggesting that the dynamics of this region are reduced at higher concentrations because of stronger self-association. This is not observed at the other two temperatures, because higher temperatures promote the formation of NMR-invisible oligomers at the higher concentration, which reduce the intensity ratio uniformly for all residues, thereby masking the residue-specific soluble monomer/multimer equilibrium effect. Micrographs of the oligomers that form at 293 and $303 \mathrm{~K}$ are shown in Figure 3D. The oligomers do not disappear when the temperature is reduced, and as a result, once the samples were heated to $303 \mathrm{~K}$, the NMR intensity remained low when the temperature was decreased back to $283 \mathrm{~K}$ (Supplementary Figure S3). SDS-PAGE data confirm that this was not because of protein degradation (Figure 3E). The fact that the transverse relaxation rate constants $\left(R_{2}\right)$ are similar for these two concentrations at all temperatures suggests that the concentration-related decrease in intensity is unlikely due to chemical exchange (e.g., a monomer-oligomer equilibrium; Figure 3F), and confirm that the reduced NMR intensity at higher temperatures is due to the formation of oligomers. Figure $3 \mathrm{G}$ shows the CD spectra of $20 \mu \mathrm{M}$ 
samples recorded at different temperatures. The $\alpha$-helical propensities estimated using the BeStSel algorithm [42,43] are $6.0 \pm 1.3 \%$ at $283 \mathrm{~K}$ and $9.4 \pm 0.5 \%$ at $303 \mathrm{~K}$ (Figure $3 \mathrm{G}$ inset). This increase in $\alpha$-helical population may be sufficient to form the oligomers observed micrographically (Figure 3D).

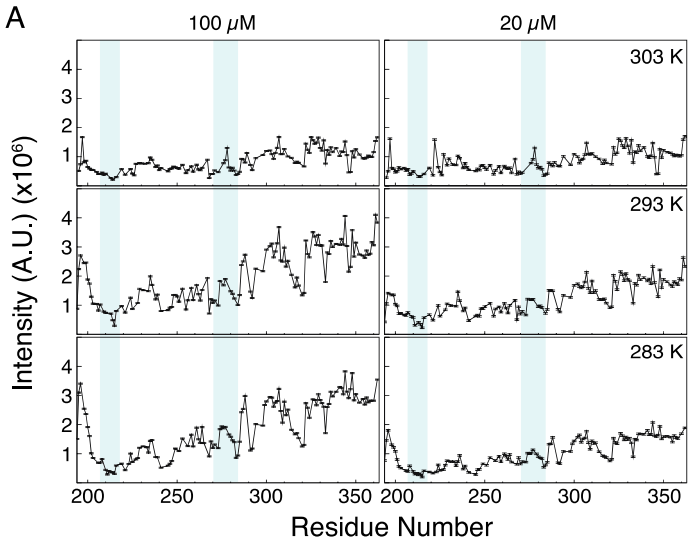

B

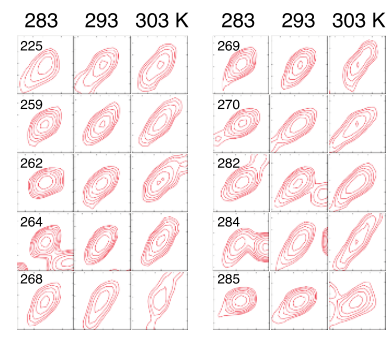

$\mathrm{F}$
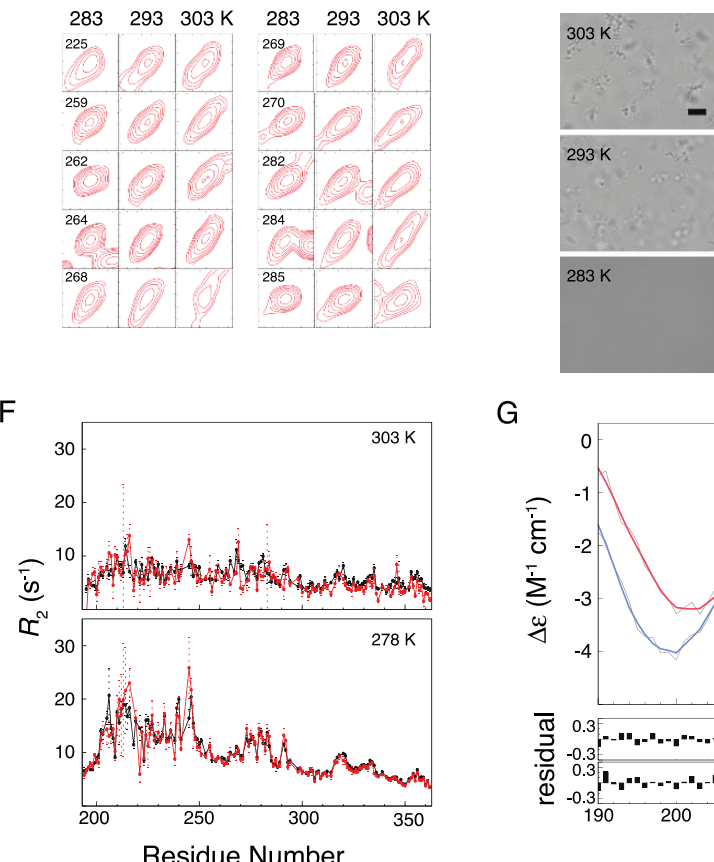

$\mathrm{G}$
C

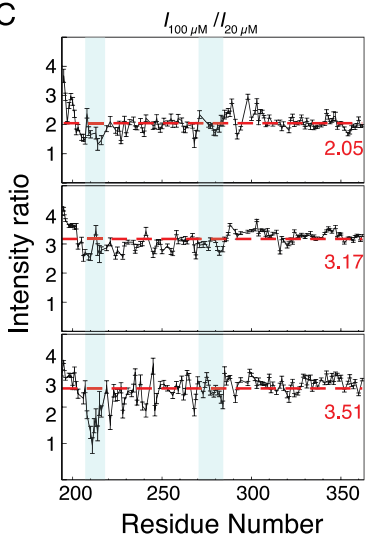

$\mathrm{E}$

Bf Af $M$
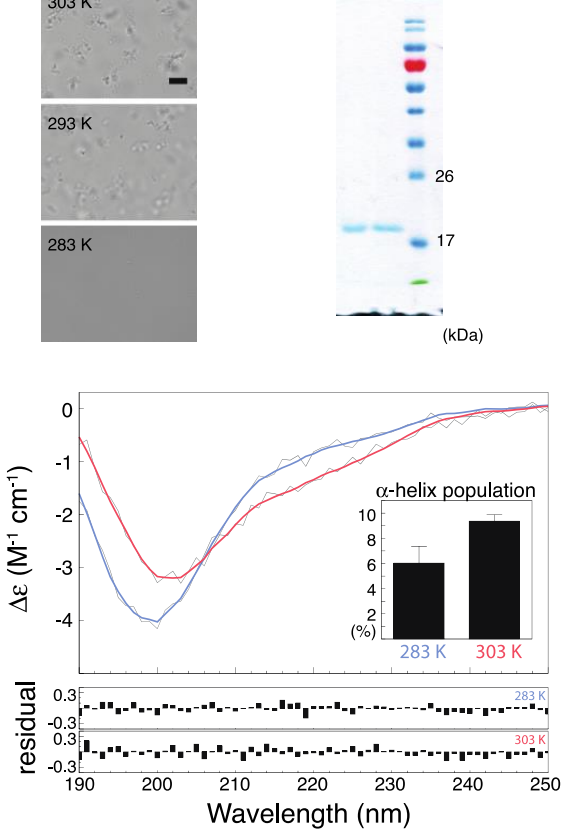

Figure 3. Temperature and concentration dependence of Musashi-1 oligomerization. (A) NMR HSQC peak intensities measured at two concentrations (100 and $20 \mu \mathrm{M})$ and three temperatures $(283,293$, and $303 \mathrm{~K}$ ) at $\mathrm{pH}$ 5.5. Regions with $\alpha$-helical propensity are shaded blue. (B) Selected peaks showing evidence of line-broadening with increasing temperature. The residue number is indicated on the left-upper corner in each panel. (C) Peak intensity ratios between 100 and $20 \mu \mathrm{M}$ samples. The numbers (red) indicate the averaged values. (D) Micrographs of the oligomers formed at 293 and $303 \mathrm{~K}$ (scale bar $=10 \mu \mathrm{m}$ ) of $20 \mu \mathrm{M}$ samples. (E) SDS-PAGE analysis of protein integrity before (Bf) and after (Af) having increased the temperature above the oligomerization threshold. (F) Transverse relaxation rate constants $\left(R_{2}\right)$ at 278 and $303 \mathrm{~K}$ for $20 \mu \mathrm{M}$ (red) and $100 \mu \mathrm{M}$ (black) samples. (G) Circular dichroism spectra for $20 \mu \mathrm{M}$ samples ( $\mathrm{pH} 5.5$ ) at $283 \mathrm{~K}$ (blue) and $303 \mathrm{~K}$ (red) fitted using the BeStSel algorithm (gray lines: raw data). The inset compares the average $\alpha$-helical populations at the two temperatures (three repeats; mean $\pm \mathrm{SD}$ ). Fitting residuals are shown in the lower panel. 


\subsection{Formation of Musashi-1 Oligomers in a Time-Dependent Manner and at a Higher $p H$}

Figure 4A illustrates how the NMR peak intensities decreased over time: by more than $80 \%$ overall after $24 \mathrm{~h}$ for the $100 \mu \mathrm{M}$ sample. SDS-PAGE shows that this is not because of sample degradation (Figure 4B). The NMR signal intensity also decreased overall on increasing the $\mathrm{pH}$ of the sample to 5.7 or 6 (Figure 4C), again, not because of protein degradation (Figure 4D). These results suggest that increasing the $\mathrm{pH}$ alters the balance between electrostatic repulsion (from the net positive charge $(+2)$ of the IDR) and hydrophobic attraction in favor of the latter, leading to oligomerization. Similar assembly behavior was observed by using microscopy after longer incubation times at $\mathrm{pH} 5.5$ or a freshly prepared sample at $\mathrm{pH} 6$ (Figure 4E,F). No fluorescence signals were observed in ThT assays, indicating that there are no cross-beta structures in the oligomers (Figure 4G). (Note that fluorescence signals from cross-beta structures were observed in control ThT assays performed on the C-terminal ID domain of TDP-43). The precipitation of the protein made it difficult to use CD spectroscopy to estimate its secondary structure, as the $\Delta \varepsilon$ values (Equation (1)) used as input for the program became more uncertain as aggregates formed and the signal intensity decreased.
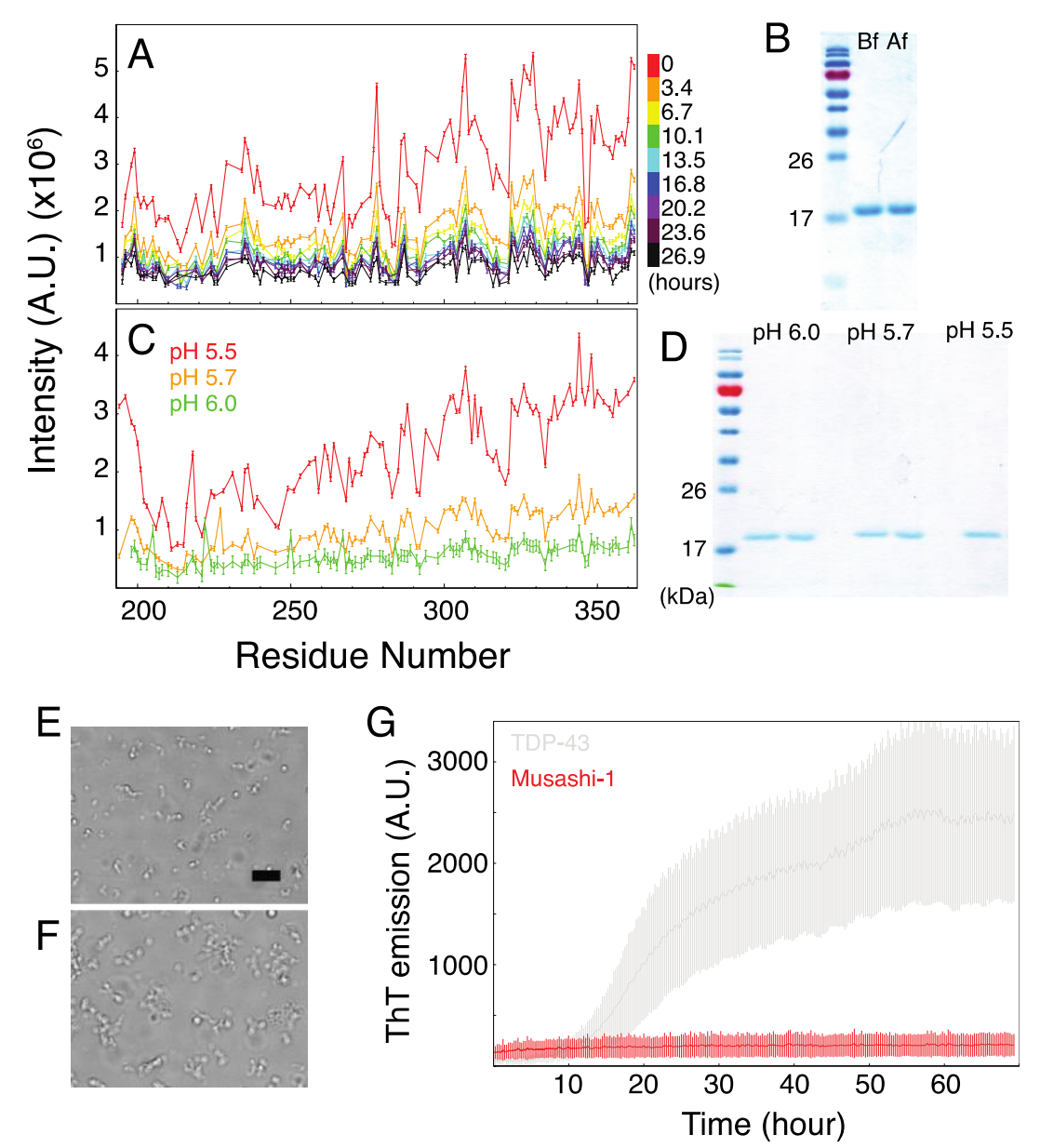

Figure 4. Analysis of the non-cross-beta Musashi-1 oligomers formed at lower $\mathrm{pHs}$ and after prolonged incubation. (A) Decrease in NMR HSQC peak intensity as a function of time. Data collected at 303 $\mathrm{K}, \mathrm{pH}$ 5.5. (B) SDS-PAGE analysis of protein integrity before (Bf) and after (Af) the one-day NMR experiments, whose results are shown in panel A. (C) NMR HSQC peak intensities at $283 \mathrm{~K}$ and pH 5.5, 5.7, and 6.0 and $283 \mathrm{~K}$. (D) SDS-PAGE analyses of the samples prepared at pH 5.5, 5.7, and 6.0. (E,F) Micrographs of samples (E) incubated at $303 \mathrm{~K}$ for $24 \mathrm{~h}$ at $\mathrm{pH} 5.5$ or $(\mathbf{F})$ freshly prepared at pH 6. Scale bar $=10 \mu \mathrm{m}$. (G) ThT assay of Musashi-1 (red) and the C-terminal domain of TDP-43 (control experiment; gray). 


\subsection{The Role of Polyalanine Tracts in Musashi-1 and in RBPs in General}

The structured RNA recognition domains of RBPs have binding pockets that have evolved to identify specific nucleic acids sequences. However, how RBPs are recruited to the gene-regulation machinery remains largely unknown. Most RBPs have IDRs whose role in controlling the entire proteins' location has only recently come to light. The features of these IDRs, including [G/S]-[F/Y/W]-[G/S] motifs [17,44], cation- $\pi$ interactions [16,18], charge-charge interactions [45], and prion-like behavior [46], lead them to assemble in response to environmental changes. Polyalanine tracts may play a similar role in the regulation of RBP assembly, as shown here for Musashi-1. Polyalanine tracts have been implicated in many diseases [47] and can act as nuclear export signals [48]. The assembly of polyalanine stretches into $\alpha$-helical clusters without forming amyloid-fibrils has also been demonstrated in both model peptides and proteins with polyalanine tracts [49]. Recent studies on aggregation-prone proteins and those with prion-like domains have shown that forming higher-order oligomers is their physiological role, albeit at the price of pathological aggregation, when the process is perturbed [50]. The same reasoning can be applied to polyalanine tracts, in the sense that, although they can induce the formation of oligomers that in turn promote amyloid formation [49], they may also have physiologically important roles in the formation of higher-order assemblies.

Among the 20,000+ human protein sequences in the UniProtKB/Swiss-Prot database, gene ontology (GO) annotations indicate that about $20.3 \%$ (listed in the Supporting Information) are RNA-related (including RNA polymerases associated functions), and 7.7\% are specifically related to "RNA binding". The proportion of proteins with polyalanine tracts (5-20 repeats) that are RNA-related is much higher; for example, more than $60 \%$ of those with $7-16$ repeats are associated to RNA-related function. Only considering proteins tagged as "RNA binding", the proportion of proteins with stretches of 5-10 alanine repeats can be twice as high as in the database as a whole (Figure 5A; Supplementary Table S2). There is, therefore, an association between the presence of polyalanine tracts and RNA-related function.
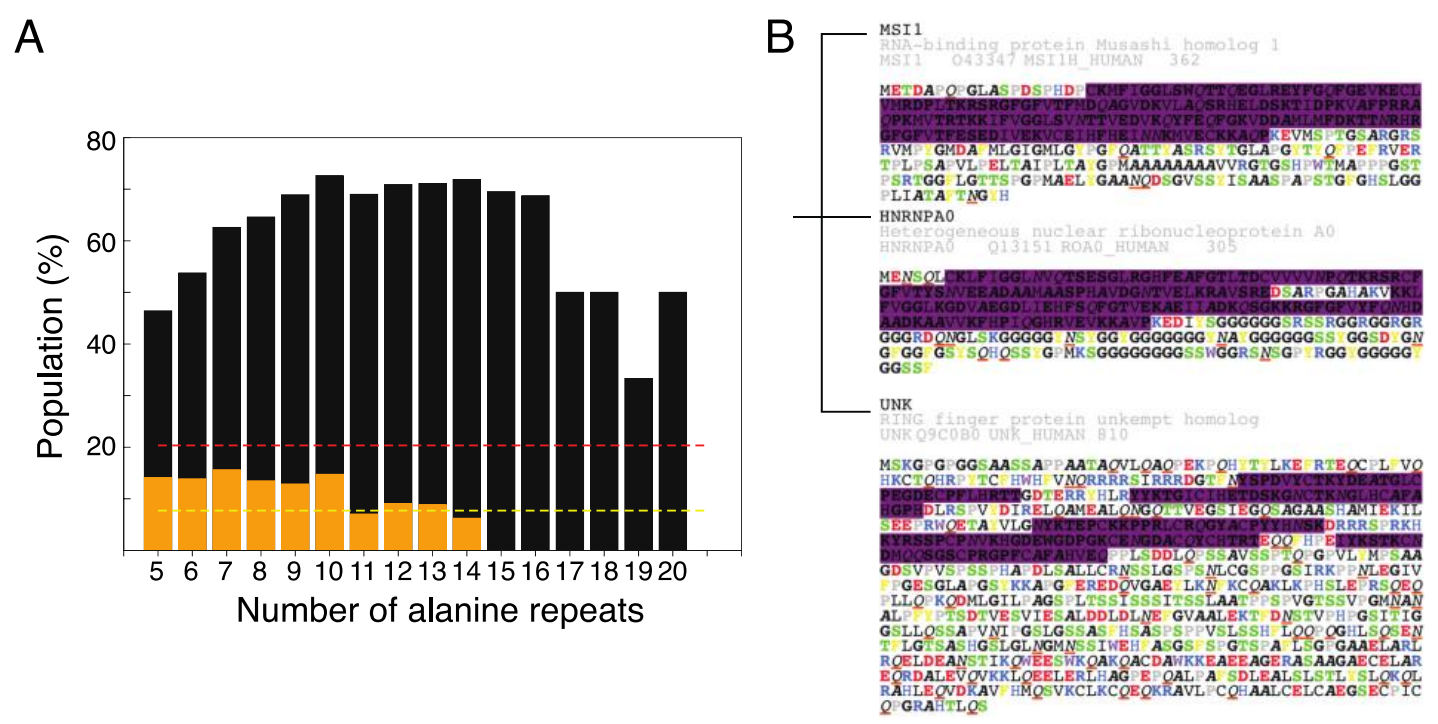

Figure 5. Polyalanine tracts are a common feature of RNA related proteins, and may be one of the ways in which RBPs self-assemble through their IDRs. (A) Bioinformatics analysis of the proportions of human proteins with different lengths of alanine repeats (from 5 to 20) either related to RNA function (black bars; the red dashed line shows the proportion overall) or specifically labeled "RNA binding" (orange bars; overall proportion, yellow dashed line). (B) Illustration of the differences in the IDRs of RBPs that bind to similar RNA motifs. The purple shaded regions are those identified by PROSITE as RNA recognition motifs. The amino acids are colored according to their physical properties (positive charge: blue; negative charge: red; F/Y: yellow; W: purple; S/T (potential phosphorylation site for the addition of negative charges): green; P: gray; A: italic-bold black; $\mathrm{Q} / \mathrm{N}$ : red underlined italic). 
In a recent study [51], Dominguez et al. purified the RNA recognition domains of a representative group of RBPs, identified their interacting RNA motifs, and then hierarchically clustered the RBPs in terms of their RNA-binding motifs. Roughly a quarter of these RBPs (18 out of 76) have polyalanine tracts ranging from 5 to 13 repeats (Supplementary Table S3), in agreement with our hypothesis that polyalanine tracts are one of the many features of RBP IDRs. More importantly, while those RBPs bind to similar RNA motifs, the physicochemical properties of their disordered regions have little in common. For example, the polyalanine feature of Musashi-1 (see Reference [51]) is not found in the IDRs from the same groups of RBPs that binds similar RNA-motif: UNK (which has charged blocks) or hnRNPA0 (which has G/S-F/Y/W-G/S motifs; Figure 5B), and there are other examples in other RNA-motif groups (Supplementary Figure S4). Even though some RBPs have similar RNA-binding motifs, their IDRs may have evolved different physical properties that ensure specific spatiotemporal regulation.

This focus on continuous polyalanine tracts may be too restrictive, and the above analysis may have underestimated the importance of $\alpha$-helix. Many other types of amino acids can form $\alpha$-helices, and many polyalanine tracts in the database are non-continuous. For example, the IDR of TDP-43 has a transient $\alpha$-helical region [23] (primary sequence, AMMAAAQAA) that is involved in self-association. Furthermore, a disrupted polyalanine tract may still contribute to self-assembly in combination with a few [G/S]-[F/Y/W]-[G/S] motifs or an increased prion-like propensity (Supplementary Figure S1).

\section{Material and Methods}

\subsection{Musashi-1 Primary Sequence Analysis}

The primary sequence of full-length Musashi-1 was taken from the UniProt database (entry number O43347) and used as input for the programs PROSITE [32], PONDR [37], ProtScale [52], FoldIndex [36], PLAAC [39], and PASTA [40], to predict the properties of the protein.

\subsection{Polyalanine Tracts Analysis}

The UniProt Knowledgebase of manually curated human protein information (UniProtKB/Swiss-Prot, entries for 20367 human proteins as of 8 January 2020) was downloaded from the UniProt website [53]. Proteins with different lengths of polyalanine tracts were extracted, using the "Peptide search" function on the same website. Proteins with RNA-related keywords in gene ontology annotations were counted, using an in-house script.

\subsection{DNA Construct}

The cDNA of Musashi-1 was provided by Dr. Wei-Yi Chen (NYMU). The C-terminal domain (residue numbers 194 to 362) was cloned to a pET-21 vector, using NdeI and XhoI restriction enzymes. A hexa-histidine tag was added to the $\mathrm{N}$-terminus for purification. No further non-native residues were added. To assist NMR assignment, four constructs with deleted fragments were prepared, using the primers listed in Supplementary Table S1. All constructs were fully sequenced.

\subsection{Protein Expression and Purification}

Single colonies of transformed E. coli. BL21 (DE3) or Rosetta were selected from an ampicillin agar plate and used to inoculate $5.0 \mathrm{~mL}$ of lysogeny broth containing $0.1 \mathrm{mg} \cdot \mathrm{mL}^{-1}$ ampicillin. The pre-culture was left in a $37^{\circ} \mathrm{C}$ shaker, overnight, and used to inoculate $500 \mathrm{~mL}$ of lysogeny broth or minimal M9 medium (containing ${ }^{15} \mathrm{NH}_{4} \mathrm{Cl}$ and/or ${ }^{13} \mathrm{C}$-glucose for isotope labeling). The growth cultures were left in a $37^{\circ} \mathrm{C}$ shaker and shaken vigorously until the O.D $\mathrm{D}_{600}$ reached 0.6 . The cells were induced with a final concentration of $1 \mathrm{mM}$ isopropyl $\beta$-D-1-thiogalactopyranoside and left shaking at $25{ }^{\circ} \mathrm{C}$, overnight. The harvested cells were lysed by sonication in $20 \mathrm{mM}$ Tris buffer at $\mathrm{pH} 8$. After centrifugation (Beckman JA25.5, $30 \mathrm{~min}, 18,000 \mathrm{rpm}$, at $4{ }^{\circ} \mathrm{C}$ ), the inclusion bodies were dissolved with the same lysis buffer, with an additional $8 \mathrm{M}$ urea. After the second centrifugation (10,000 rpm, $30 \mathrm{~min})$, the supernatant was passed through a $0.45 \mu \mathrm{m}$ filter and loaded onto a nickel-charged immobilized 
metal-ion affinity chromatography column (Qiagen, Hilden, Germany). The column was washed with ten volumes of $20 \mathrm{mM}$ Tris buffer with $8 \mathrm{M}$ urea at $\mathrm{pH} 8$ to remove non-specific binding proteins. The target protein was eluted with an additional $500 \mathrm{mM}$ imidazole in the same wash buffer. The eluted sample was acidified, using trifluoroacetic acid, to a $\mathrm{pH}$ lower than 3 , and then loaded into a $\mathrm{C} 4$ reverse-phase column (Thermo Scientific Inc., MA, USA). The protein was eluted with an increasing gradient of acetonitrile mixed with triple-distilled water, using an HPLC system. The eluted sample was immediately frozen with liquid nitrogen and lyophilized. The lyophilized sample was stored in a drying cabinet, until use.

\subsection{Chemical Shift Assignment}

The assignment experiments were performed on a Bruker AVANCE $800 \mathrm{MHz}$ spectrometer, at $283 \mathrm{~K}$. A denaturation-then-titration strategy (assigning the protein under harsh conditions and then titrating to physiological conditions; see Supplementary Information) was used to assign the chemical shifts of the protein. In addition to standard pulse sequences (HNCO, $\mathrm{HN}(\mathrm{CA}) \mathrm{CO}, \mathrm{HNCA}, \mathrm{HN}(\mathrm{CO}) \mathrm{CA}$, $\mathrm{HNCACB}$, and $\mathrm{CBCA}(\mathrm{CO}) \mathrm{NH})$, we also used $(\mathrm{H}) \mathrm{N}(\mathrm{COCO}) \mathrm{NH}$ and $(\mathrm{HN}) \mathrm{CO}(\mathrm{CO}) \mathrm{NH}[54]$ to complete the sequential assignments of long-range $(i, i+2)$ backbone nitrogen and carbonyl carbon atoms separated by prolines. Different fragments were created to confirm the assignment (see Supplementary Information). Secondary chemical shifts were analyzed by using Kjaergaard et al.'s database of random coil shifts [55]. Secondary structure probabilities based on the chemical shifts were calculated by using the $\delta 2 \mathrm{D}$ program [41].

\subsection{NMR Experiments and Analysis}

The urea and $\mathrm{pH}$ titration experiments were monitored, using HSQC spectra [56] (with WATERGATE [57] solvent suppression) recorded on Bruker AVANCE III 600 and $850 \mathrm{MHz}$ spectrometers. All the samples were freshly prepared: The estimated amount of lyophilized sample required was dissolved in $20 \mathrm{mM}$ MES buffer with protease inhibitor cocktail (Roche, Basel,, Switzerland); the samples were centrifuged at $12,000 \times g$ for $5 \mathrm{~min}$, to remove any aggregates; and the concentration was confirmed by measuring the absorbance at $280 \mathrm{~nm}$ on a NanoDrop spectrometer (Thermo Scientific Inc., MA, USA). Transverse relaxation rate constants were measured on the $850 \mathrm{MHz}$ spectrometer, using standard pulse sequences [58] (with delays of 17.2, 34.3, 51.5, 68.6, 120.1, and $154.4 \mathrm{~ms}$ ). Peak intensities were fitted to exponential decays with a Monte Carlo procedure, to estimate fitting error. All dynamics data were collected in an interleaved manner, with an inter scan delay of $3 \mathrm{~s}$.

\subsection{Circular Dichroism Spectroscopy}

Circular dichroism spectra were recorded by using an AVIV model 410 spectropolarimeter. A 0.1 mm cuvette was used. Data were collected between 190 and $260 \mathrm{~nm}$, with an interval of $1 \mathrm{~nm}$. Ten measurements were co-added for each data point, and all the experiments were performed in triplicate. The measured theta machine units $(\theta)$ were converted to $\Delta \varepsilon$, using the following equation [59]:

$$
\Delta \varepsilon=\theta \times \frac{0.1 \times M R W}{l \times C \times 3298}
$$

where MRW is the mean residue weight (molecular weight/residue number, in Dalton), $l$ is the path length (in $\mathrm{cm}$ ), and $C$ is the protein concentration (in $\mathrm{mg} / \mathrm{mL}$ ). The resulting curves were fitted, using the program BeStSel $[42,43]$, to estimate secondary structure populations. Samples $(20 \mu \mathrm{M})$ were prepared in $20 \mathrm{mM}$ MES buffer at $\mathrm{pH} 5.5$, at different temperatures, otherwise indicated. 


\subsection{Microscopy}

Micrographs were collected by using an Olympus BX51 device with a 40× long working-distance objective lens, and the images were recorded with a Zeiss AxioCam MRm camera. The samples were placed on a thermostatic microscope stage (THM120, Linkam Scientific Inc., Tadworth, U.K.) and were equilibrated for $5 \mathrm{~min}$, before collecting the images.

\subsection{Thioflavin T Fluorescence Assay}

A 1 M stock solution of Thioflavin T (ThT, Acros organics) was prepared in $90 \%(v / v)$ ethanol and protected from light prior to use. The ThT stock was diluted, using $20 \mathrm{mM}$ MES-NaOH buffer to obtain a $1 \mathrm{mM}$ ThT working solution. Protein sample solutions were mixed with the ThT working solution to the designed final concentration. Each sample $(120 \mu \mathrm{L})$ was distributed in a black $96-$ well plate. The plates were sealed and transferred to an Infinite 200 (TECAN) multimode microplate reader and incubated at $30^{\circ} \mathrm{C}$. The emission intensity at $480 \mathrm{~nm}$ was recorded, using slit widths of $5 \mathrm{~nm}$ for both excitation and emission. At least three independent experiments were performed for each condition.

\section{Conclusions}

While developments in cryogenic electron microscopy [60-63] have revolutionized structural biology [64], NMR spectroscopy remains the most powerful tools to study protein dynamics, especially IDRs and IDPs, with residue-specific resolution [65]. RNA-binding proteins are a large family of proteins with high sequence variability in their IDRs. This study of Musashi-1 illustrates the power of NMR spectroscopy to study disordered proteins. The assignment strategy we used can be applied to many other aggregation-prone proteins, and the chemical shift assignments here can be used to conduct further studies of how its IDRs interact with binding partners [66,67]. Indeed, some identified interacting regions cover the first $\alpha$-helix, which might be critical for their interaction [66,67]. Our results highlight Musashi-1's ability to self-assemble through interactions involving the region between the two $\alpha$-helical elements. They also provide a mechanistic explanation of how this protein forms pathological oligomers and is recruited into stress granules via its polyalanine tracts. Polyalanine tracts are found in the IDRs of many other RBPs, suggesting that they have evolved as a means to control where and when RBPs self-assemble.

Accession Numbers: The backbone chemical shift assignments of Musashi- 1 were deposited in the BMRB, under accession code 50204 .

Supplementary Materials: Supplementary materials can be found at http://www.mdpi.com/1422-0067/21/7/2289/ s1.

Author Contributions: Conceptualization, J.-r.H.; validation, T.-C.C. and J.-r.H.; formal analysis, T.-C.C. and J.-r.H.; investigation, T.-C.C. and J.-r.H.; data curation, T.-C.C. and J.-r.H.; writing, J.-r.H.; supervision, J.-r.H; funding acquisition, J.-r.H. All authors have read and agreed to the published version of the manuscript.

Funding: This research was funded by the Ministry of Science and Technology of Taiwan, grant numbers 106-2113-M-010-005-MY2 and 108-2113-M-010-005. The APC was funded by the Ministry of Science and Technology of Taiwan.

Acknowledgments: The authors thank Prof. Won-Jing Wang (NYMU) for access to the microscope, Academia Sinica High-Field NMR Center (HFNMRC) for technical support (HFNMRC is funded by Academia Sinica Core Facility and Innovative Instrument Project (AS-CFII-108-112)), the Instrumentation Centre in National Taiwan University for access to NMR spectrometers, Dr. Shing-Jong Huang (NTU) for help setting up NMR assignment experiments, and Ting Wang for initial work on this project.

Conflicts of Interest: The authors declare no conflict of interest. The funders had no role in the design of the study; in the collection, analyses, or interpretation of data; in the writing of the manuscript; or in the decision to publish the results. 


\section{Abbreviations}

$\begin{array}{ll}\text { RBP } & \text { RNA-binding proteins } \\ \text { IDP } & \text { Intrinsically disordered proteins } \\ \text { NMR } & \text { Nuclear magnetic resonance } \\ \text { CD } & \text { Circular dichroism } \\ \text { HSQC } & \text { Heteronuclear single-quantum coherence } \\ \text { SDS-PAGE } & \text { Sodium dodecyl sulfate-polyacrylamide gel electrophoresis }\end{array}$

\section{References}

1. Gerstberger, S.; Hafner, M.; Tuschl, T. A census of human RNA-binding proteins. Nat. Rev. Genet. 2014, 15, 829-845. [CrossRef] [PubMed]

2. Varadi, M.; Zsolyomi, F.; Guharoy, M.; Tompa, P. Functional Advantages of Conserved Intrinsic Disorder in RNA-Binding Proteins. PLoS ONE 2015, 10, e0139731. [CrossRef]

3. Zagrovic, B.; Bartonek, L.; Polyansky, A.A. RNA-protein interactions in an unstructured context. FEBS Lett. 2018, 592, 2901-2916. [CrossRef] [PubMed]

4. Calabretta, S.; Richard, S. Emerging Roles of Disordered Sequences in RNA-Binding Proteins. Trends Biochem. Sci. 2015, 40, 662-672. [CrossRef]

5. Jarvelin, A.I.; Noerenberg, M.; Davis, I.; Castello, A. The new (dis)order in RNA regulation. Cell Commun. Signal. 2016, 14, 9. [CrossRef] [PubMed]

6. Daubner, G.M.; Clery, A.; Allain, F.H. RRM-RNA recognition: NMR or crystallography... and new findings. Curr. Opin. Struct. Biol. 2013, 23, 100-108. [CrossRef] [PubMed]

7. Leitner, A.; Dorn, G.; Allain, F.H. Combining Mass Spectrometry (MS) and Nuclear Magnetic Resonance (NMR) Spectroscopy for Integrative Structural Biology of Protein-RNA Complexes. Cold Spring Harb. Perspect. Biol. 2019, 11, a032359. [CrossRef] [PubMed]

8. Kato, M.; Han, T.W.; Xie, S.; Shi, K.; Du, X.; Wu, L.C.; Mirzaei, H.; Goldsmith, E.J.; Longgood, J.; Pei, J.; et al. Cell-free formation of RNA granules: Low complexity sequence domains form dynamic fibers within hydrogels. Cell 2012, 149, 753-767. [CrossRef]

9. Alberti, S.; Gladfelter, A.; Mittag, T. Considerations and Challenges in Studying Liquid-Liquid Phase Separation and Biomolecular Condensates. Cell 2019, 176, 419-434. [CrossRef]

10. Banani, S.F.; Lee, H.O.; Hyman, A.A.; Rosen, M.K. Biomolecular condensates: Organizers of cellular biochemistry. Nat. Rev. Mol. Cell Biol. 2017, 18, 285-298. [CrossRef]

11. Patel, A.; Lee, H.O.; Jawerth, L.; Maharana, S.; Jahnel, M.; Hein, M.Y.; Stoynov, S.; Mahamid, J.; Saha, S.; Franzmann, T.M.; et al. A Liquid-to-Solid Phase Transition of the ALS Protein FUS Accelerated by Disease Mutation. Cell 2015, 162, 1066-1077. [CrossRef] [PubMed]

12. Molliex, A.; Temirov, J.; Lee, J.; Coughlin, M.; Kanagaraj, A.P.; Kim, H.J.; Mittag, T.; Taylor, J.P. Phase separation by low complexity domains promotes stress granule assembly and drives pathological fibrillization. Cell 2015, 163, 123-133. [CrossRef] [PubMed]

13. Yoshizawa, T.; Ali, R.; Jiou, J.; Fung, H.Y.; Burke, K.A.; Kim, S.J.; Lin, Y.; Peeples, W.B.; Saltzberg, D.; Soniat, M.; et al. Nuclear Import Receptor Inhibits Phase Separation of FUS through Binding to Multiple Sites. Cell 2018, 173, 693-705.e22. [CrossRef] [PubMed]

14. Guo, L.; Kim, H.J.; Wang, H.; Monaghan, J.; Freyermuth, F.; Sung, J.C.; O’Donovan, K.; Fare, C.M.; Diaz, Z.; Singh, N.; et al. Nuclear-Import Receptors Reverse Aberrant Phase Transitions of RNA-Binding Proteins with Prion-like Domains. Cell 2018, 173, 677-692.e20. [CrossRef]

15. Hofweber, M.; Hutten, S.; Bourgeois, B.; Spreitzer, E.; Niedner-Boblenz, A.; Schifferer, M.; Ruepp, M.D.; Simons, M.; Niessing, D.; Madl, T.; et al. Phase Separation of FUS Is Suppressed by Its Nuclear Import Receptor and Arginine Methylation. Cell 2018, 173, 706-719.e13. [CrossRef]

16. Qamar, S.; Wang, G.; Randle, S.J.; Ruggeri, F.S.; Varela, J.A.; Lin, J.Q.; Phillips, E.C.; Miyashita, A.; Williams, D.; Ströhl, F.; et al. FUS Phase Separation Is Modulated by a Molecular Chaperone and Methylation of Arginine Cation-pi Interactions. Cell 2018, 173, 720-734.e15. [CrossRef]

17. Lin, Y.; Currie, S.L.; Rosen, M.K. Intrinsically disordered sequences enable modulation of protein phase separation through distributed tyrosine motifs. J. Biol. Chem. 2017, 292, 19110-19120. [CrossRef] 
18. Wang, J.; Choi, J.M.; Holehouse, A.S.; Lee, H.O.; Zhang, X.; Jahnel, M.; Maharana, S.; Lemaitre, R.; Pozniakovsky, A.; Drechsel, D.; et al. A Molecular Grammar Governing the Driving Forces for Phase Separation of Prion-like RNA Binding Proteins. Cell 2018, 174, 688-699.e16. [CrossRef]

19. Ying, Y.; Wang, X.J.; Vuong, C.K.; Lin, C.H.; Damianov, A.; Black, D.L. Splicing Activation by Rbfox Requires Self-Aggregation through Its Tyrosine-Rich Domain. Cell 2017, 170, 312-323.e10. [CrossRef]

20. Gueroussov, S.; Weatheritt, R.J.; O'Hanlon, D.; Lin, Z.Y.; Narula, A.; Gingras, A.C.; Blencowe, B.J. Regulatory Expansion in Mammals of Multivalent hnRNP Assemblies that Globally Control Alternative Splicing. Cell 2017, 170, 324-339.e23. [CrossRef]

21. Conicella, A.E.; Zerze, G.H.; Mittal, J.; Fawzi, N.L. ALS Mutations Disrupt Phase Separation Mediated by alpha-Helical Structure in the TDP-43 Low-Complexity C-Terminal Domain. Structure 2016, 24, 1537-1549. [CrossRef] [PubMed]

22. Burke, K.A.; Janke, A.M.; Rhine, C.L.; Fawzi, N.L. Residue-by-Residue View of In Vitro FUS Granules that Bind the C-Terminal Domain of RNA Polymerase II. Mol. Cell 2015, 60, 231-241. [CrossRef] [PubMed]

23. Li, H.R.; Chen, T.C.; Hsiao, C.L.; Shi, L.; Chou, C.Y.; Huang, J.R. The physical forces mediating self-association and phase-separation in the C-terminal domain of TDP-43. Biochim. Biophys. Acta 2018, 1866, 214-223. [CrossRef] [PubMed]

24. Ryan, V.H.; Dignon, G.L.; Zerze, G.H.; Chabata, C.V.; Silva, R.; Conicella, A.E.; Amaya, J.; Burke, K.A.; Mittal, J.; Fawzi, N.L. Mechanistic View of hnRNPA2 Low-Complexity Domain Structure, Interactions, and Phase Separation Altered by Mutation and Arginine Methylation. Mol. Cell 2018, 69, 465-479.e7. [CrossRef] [PubMed]

25. Fox, R.G.; Park, F.D.; Koechlein, C.S.; Kritzik, M.; Reya, T. Musashi signaling in stem cells and cancer. Annu. Rev. Cell Dev. Biol. 2015, 31, 249-267. [CrossRef] [PubMed]

26. Sengupta, U.; Montalbano, M.; McAllen, S.; Minuesa, G.; Kharas, M.; Kayed, R. Formation of Toxic Oligomeric Assemblies of RNA-binding Protein: Musashi in Alzheimer's disease. Acta Neuropathol. Commun. 2018, 6, 113. [CrossRef] [PubMed]

27. Montalbano, M.; McAllen, S.; Sengupta, U.; Puangmalai, N.; Bhatt, N.; Ellsworth, A.; Kayed, R. Tau oligomers mediate aggregation of RNA-binding proteins Musashi1 and Musashi2 inducing Lamin alteration. Aging Cell 2019, 18, e13035. [CrossRef] [PubMed]

28. Wang, I.F.; Wu, L.S.; Shen, C.K. TDP-43: An emerging new player in neurodegenerative diseases. Trends Mol. Med. 2008, 14, 479-485. [CrossRef]

29. Taylor, J.P.; Brown, R.H., Jr.; Cleveland, D.W. Decoding ALS: From genes to mechanism. Nature 2016, 539, 197-206. [CrossRef]

30. Chen, H.Y.; Lin, L.T.; Wang, M.L.; Tsai, K.L.; Huang, P.I.; Yang, Y.P.; Lee, Y.Y.; Chen, Y.W.; Lo, W.L.; Lan, Y.T.; et al. Musashi-1 promotes chemoresistant granule formation by PKR/eIF2alpha signalling cascade in refractory glioblastoma. Biochim. Biophys. Acta Mol. Basis Dis. 2018, 1864, 1850-1861. [CrossRef]

31. Chiou, G.Y.; Yang, T.W.; Huang, C.C.; Tang, C.Y.; Yen, J.Y.; Tsai, M.C.; Chen, H.Y.; Fadhilah, N.; Lin, C.C.; Jong, Y.J. Musashi-1 promotes a cancer stem cell lineage and chemoresistance in colorectal cancer cells. Sci. Rep. 2017, 7, 2172. [CrossRef]

32. Sigrist, C.J.; Cerutti, L.; De Castro, E.; Langendijk-Genevaux, P.S.; Bulliard, V.; Bairoch, A.; Hulo, N. PROSITE, a protein domain database for functional characterization and annotation. Nucleic Acids Res. 2010, 38, D161-D166. [CrossRef] [PubMed]

33. Iwaoka, R.; Nagata, T.; Tsuda, K.; Imai, T.; Okano, H.; Kobayashi, N.; Katahira, M. Structural Insight into the Recognition of r(UAG) by Musashi-1 RBD2, and Construction of a Model of Musashi-1 RBD1-2 Bound to the Minimum Target RNA. Molecules 2017, 22, 1207. [CrossRef] [PubMed]

34. Ohyama, T.; Nagata, T.; Tsuda, K.; Kobayashi, N.; Imai, T.; Okano, H.; Yamazaki, T.; Katahira, M. Structure of Musashi1 in a complex with target RNA: The role of aromatic stacking interactions. Nucleic Acids Res. 2012, 40, 3218-3231. [CrossRef]

35. Wootton, J.C. Non-globular domains in protein sequences: Automated segmentation using complexity measures. Comput. Chem. 1994, 18, 269-285. [CrossRef]

36. Prilusky, J.; Felder, C.E.; Zeev-Ben-Mordehai, T.; Rydberg, E.H.; Man, O.; Beckmann, J.S.; Silman, I.; Sussman, J.L. FoldIndex: A simple tool to predict whether a given protein sequence is intrinsically unfolded. Bioinformatics 2005, 21, 3435-3438. [CrossRef] [PubMed] 
37. Radivojac, P.; Obradović, Z.; Brown, C.J.; Dunker, A.K. Prediction of boundaries between intrinsically ordered and disordered protein regions. Pac. Symp. Biocomput. 2003, 8, 216-227.

38. Kyte, J.; Doolittle, R.F. A simple method for displaying the hydropathic character of a protein. J. Mol. Biol. 1982, 157, 105-132. [CrossRef]

39. Lancaster, A.K.; Nutter-Upham, A.; Lindquist, S.; King, O.D. PLAAC: A web and command-line application to identify proteins with prion-like amino acid composition. Bioinformatics 2014, 30, 2501-2502. [CrossRef]

40. Walsh, I.; Seno, F.; Tosatto, S.C.; Trovato, A. PASTA 2.0: An improved server for protein aggregation prediction. Nucleic Acids Res. 2014, 42, W301-W307. [CrossRef]

41. Camilloni, C.; De Simone, A.; Vranken, W.F.; Vendruscolo, M. Determination of secondary structure populations in disordered states of proteins using nuclear magnetic resonance chemical shifts. Biochemistry 2012, 51, 2224-2231. [CrossRef] [PubMed]

42. Micsonai, A.; Wien, F.; Bulyáki, É.; Kun, J.; Moussong, É.; Lee, Y.H.; Goto, Y.; Réfrégiers, M.; Kardos, J. BeStSel: A web server for accurate protein secondary structure prediction and fold recognition from the circular dichroism spectra. Nucleic Acids Res. 2018, 46, W315-W322. [CrossRef] [PubMed]

43. Micsonai, A.; Wien, F.; Kernya, L.; Lee, Y.H.; Goto, Y.; Réfrégiers, M.; Kardos, J. Accurate secondary structure prediction and fold recognition for circular dichroism spectroscopy. Proc. Natl. Acad. Sci. USA 2015, 112, E3095-E3103. [CrossRef]

44. Xiang, S.; Kato, M.; Wu, L.C.; Lin, Y.; Ding, M.; Zhang, Y.; Yu, Y.; McKnight, S.L. The LC Domain of hnRNPA2 Adopts Similar Conformations in Hydrogel Polymers, Liquid-like Droplets, and Nuclei. Cell 2015, 163, 829-839. [CrossRef] [PubMed]

45. Nott, T.J.; Petsalaki, E.; Farber, P.; Jervis, D.; Fussner, E.; Plochowietz, A.; Craggs, T.D.; Bazett-Jones, D.P.; Pawson, T.; Forman-Kay, J.D.; et al. Phase transition of a disordered nuage protein generates environmentally responsive membraneless organelles. Mol. Cell 2015, 57, 936-947. [CrossRef]

46. Fang, X.; Wang, L.; Ishikawa, R.; Li, Y.; Fiedler, M.; Liu, F.; Calder, G.; Rowan, B.; Weigel, D.; Li, P.; et al. Arabidopsis FLL2 promotes liquid-liquid phase separation of polyadenylation complexes. Nature 2019, 569, 265-269. [CrossRef]

47. Brown, L.Y.; Brown, S.A. Alanine tracts: The expanding story of human illness and trinucleotide repeats. Trends Genet. 2004, 20, 51-58. [CrossRef]

48. Li, L.; Ng, N.K.; Koon, A.C.; Chan, H.Y. Expanded polyalanine tracts function as nuclear export signals and promote protein mislocalization via eEF1A1 factor. J. Biol. Chem. 2017, 292, 5784-5800. [CrossRef]

49. Polling, S.; Ormsby, A.R.; Wood, R.J.; Lee, K.; Shoubridge, C.; Hughes, J.N.; Thomas, P.Q.; Griffin, M.D.; Hill, A.F.; Bowden, Q.; et al. Polyalanine expansions drive a shift into alpha-helical clusters without amyloid-fibril formation. Nat. Struct. Mol. Biol. 2015, 22, 1008-1015. [CrossRef]

50. Itakura, A.K.; Futia, R.A.; Jarosz, D.F. It Pays To Be in Phase. Biochemistry 2018, 57, 2520-2529. [CrossRef]

51. Dominguez, D.; Freese, P.; Alexis, M.S.; Su, A.; Hochman, M.; Palden, T.; Bazile, C.; Lambert, N.J.; Van Nostrand, E.L.; Pratt, G.A.; et al. Sequence, Structure, and Context Preferences of Human RNA Binding Proteins. Mol. Cell 2018, 70, 854-867.e9. [CrossRef] [PubMed]

52. Wilkins, M.R.; Gasteiger, E.; Bairoch, A.; Sanchez, J.C.; Williams, K.L.; Appel, R.D.; Hochstrasser, D.F. Protein identification and analysis tools in the ExPASy server. Methods Mol. Biol. 1999, 112, 531-552.

53. UniProt Consortium. UniProt: A worldwide hub of protein knowledge. Nucleic Acids Res. 2019, 47, D506-D515. [CrossRef]

54. Yoshimura, Y.; Kulminskaya, N.V.; Mulder, F.A. Easy and unambiguous sequential assignments of intrinsically disordered proteins by correlating the backbone $15 \mathrm{~N}$ or $13 \mathrm{C}^{\prime}$ chemical shifts of multiple contiguous residues in highly resolved 3D spectra. J. Biomol. NMR 2015, 61, 109-121. [CrossRef] [PubMed]

55. Kjaergaard, M.; Brander, S.; Poulsen, F.M. Random coil chemical shift for intrinsically disordered proteins: Effects of temperature and pH. J. Biomol. NMR 2011, 49, 139-149. [CrossRef] [PubMed]

56. Piotto, M.; Saudek, V.; Sklenar, V. Gradient-tailored excitation for single-quantum NMR spectroscopy of aqueous solutions. J. Biomol. NMR 1992, 2, 661-665. [CrossRef]

57. Liu, M.; Mao, X.A.; Ye, C.; Huang, H.; Nicholson, J.K.; Lindon, J.C. Improved WATERGATE Pulse Sequences for Solvent Suppression in NMR Spectroscopy. J. Magn. Reson. 1998, 132, 125-129. [CrossRef]

58. Kay, L.E.; Torchia, D.A.; Bax, A. Backbone dynamics of proteins as studied by $15 \mathrm{~N}$ inverse detected heteronuclear NMR spectroscopy: Application to staphylococcal nuclease. Biochemistry 1989, 28, 8972-8979. [CrossRef] 
59. Greenfield, N.J. Using circular dichroism spectra to estimate protein secondary structure. Nat. Protoc. 2006, 1, 2876-2890. [CrossRef]

60. Dubochet, J. On the Development of Electron Cryo-Microscopy (Nobel Lecture). Angew. Chem. Int. Ed. 2018, 57, 10842-10846. [CrossRef]

61. Henderson, R. From Electron Crystallography to Single Particle CryoEM (Nobel Lecture). Angew. Chem. Int. Ed. 2018, 57, 10804-10825. [CrossRef] [PubMed]

62. Frank, J. Single-Particle Reconstruction of Biological Molecules-Story in a Sample (Nobel Lecture). Angezw. Chem. Int. Ed. 2018, 57, 10826-10841. [CrossRef] [PubMed]

63. Fernandez-Leiro, R.; Scheres, S.H. Unravelling biological macromolecules with cryo-electron microscopy. Nature 2016, 537, 339-346. [CrossRef] [PubMed]

64. Callaway, E. The revolution will not be crystallized: A new method sweeps through structural biology. Nature 2015, 525, 172-174. [CrossRef] [PubMed]

65. Dyson, H.J.; Wright, P.E. Perspective: The essential role of NMR in the discovery and characterization of intrinsically disordered proteins. J. Biomol. NMR 2019, 73, 651-659. [CrossRef] [PubMed]

66. Kawahara, H.; Imai, T.; Imataka, H.; Tsujimoto, M.; Matsumoto, K.; Okano, H. Neural RNA-binding protein Musashi1 inhibits translation initiation by competing with eIF4G for PABP. J. Cell Biol. 2008, 181, 639-653. [CrossRef]

67. Cragle, C.; MacNicol, A.M. Musashi protein-directed translational activation of target mRNAs is mediated by the poly(A) polymerase, germ line development defective-2. J. Biol. Chem. 2014, 289, 14239-14251. [CrossRef]

(C) 2020 by the authors. Licensee MDPI, Basel, Switzerland. This article is an open access article distributed under the terms and conditions of the Creative Commons Attribution (CC BY) license (http://creativecommons.org/licenses/by/4.0/). 